\title{
ANALISIS TERHADAP PEMECATAN ANGGOTA KEPOLISIAN MELALUI SIDANG KODE ETIK PROFESI PADA WILAYAH KEPOLISIAN DAERAH SULAWESI SELATAN
}

\author{
Analysis of The Signing of Police Members Through A Professional Code of Conduct \\ in South Sulawesi Regional Police Area \\ Husain ${ }^{1}$, Ruslan Renggong ${ }^{2}$, Abd.Salam Siku ${ }^{2}$ \\ ${ }^{1}$ Mahasiswa Program Studi Ilmu Hukum Program Pascasarjana Universitas Bosowa \\ ${ }^{2}$ Prodi Ilmu Hukum Universitas Bosowa \\ Email: husain09haruna@gmail.com
}

Diterima: 08 Agustus 2019/Disetujui: 09 Desember 2019

\begin{abstract}
ABSTRAK
Penelitian ini bertujuan untuk mengetahui bentuk pelanggaran dan penerapan sanksi yang diberikan kepada anggota Polri yang melanggar kode etik profesi kepolisian, serta dampaknya akibat proses hukum yang timbul setelah penjatuhan putusan sidang Kode Etik Profesi Polri di Wilayah Hukum Kepolisian Daerah Sulawesi Selatan. Penelitian ini dilaksanakan pada Kantor Kepolisian Daerah (POLDA) Sulawesi Selatan, dengan menggunakan pendekatan normatif empiris, artinya pendekatan yang dilakukan untuk menganalisis tentang sejauhmana suatu peraturan atau hukum yang sedang berlaku secara efektif dalam lingkungan Polri mengenai pemecatan anggota Polri melalui sidang Kode Etik Profesi pada wilayah Kepolisian Daerah Sulawesi Selatan. Hasil penelitian ini menunjukkan bahwa bentuk pelanggaran dan penerapan sanksi yang diberikan kepada anggota Polri yang melanggar Kode Etik Profesi Polri (KEPP) di wilayah hukum Kepolisian Daerah Sulawesi Selatan, pada tahun 2016-2019 telah terjadi pelanggaran dan sanksi KEPP sebanyak 75 kasus. Sedangkan dalam penjatuhan putusan sidang Komisi Kode Etik Polri (KKEP) dengan sanksi rekomendasi Pemberhentian Tidak dengan Hormat (PTDH) dari tahun 2016-2019 sebanyak 39 kasus PTDH.
\end{abstract}

Kata Kunci: Polri, Pelanggaran, Sanksi, KEPP, PTDH

\section{ABSTRACT}

This study aims to determine the form of violations and the application of sanctions imposed on members of the National Police who violate the police profession code of ethics, and their impact due to the legal process arising after the decision of the Polri Profession Code of Ethics hearing in the South Sulawesi Regional Police Legal Area. This research was carried out at the Regional Police Office (RPO) of South Sulawes, using an empirical normative approach, meaning the approach taken to analyze the extent to which a regulation or law is being applied effectively within the National Police regarding the dismissal of members of the National Police through the Professional Code of Ethics in the region South Sulawesi Regional Police. The results of this study indicate that the form of violations and the application of sanctions given to members of the Police who violated the National Police Profession Code of Ethics (PCE) in the South Sulawesi Regional Police jurisdiction, violations and PCE sanctions occurred in 75 cases. Whereas in the ruling of the decision of the National Police Ethics Code (PCE) Commission with recommended sanctions, the Dismissal Not with Resignation (DNWR) from 2016-2019 was 39 cases of DNWR.

Keywords: National Police, Violations, Sanctions, PCE, DNWR

\section{PENDAHULUAN}

Kepolisian adalah salah satu aparat penegak hukum yang selalu berada di garis terdepan dalam mengayomi, melayani dan melindungi masyarakat. Dalam menjalankan tugasnya tidaklah mudah dalam menghadapi masalah-masalah yang berada di dalam masyarakat (Syamsiar, 2019).

Seringnya terjadi fenomena dalam institusi kepolisian, seorang anggota Polri yang seharusnya menjadi pelindung dan pengayom masyarakat justru melakukan perbuatan tercela dan melanggar ketentuan hukum yang berlaku.
Tidak jarang terdapat anggota Polri yang bertindak melawan hu-kum dan tidak mengindahkan norma agama, kesopanan, ke-susilaan, serta tidak menghargai hak-hak asasi manusia (Ali, 2007;Abintro, 2015).

Pada kenyataan di lapangan masih banyak ditemukan pelanggaran yang dilakukan oleh anggota Polri. Hal tersebut tentunya membawa dampak terhadap terciptanya opini publik yang negatif dan timbulnya citra buruk serta sikap antipati masyarakat, sehingga pelaksanaan tugas di lapangan tidak dapat dilaksanakan secara optimal karena kurang didu- 
kung dan adanya rasa ketidakpercayaan masyarakat terhadap Polri (Sadjijono, 2010).

Pelanggaran perilaku oknum anggota Polri tersebut merupakan pelanggaran terhadap peraturan disiplin Kepolisian maka dari itu dibutuhkan upaya penegakan Kode Etik Profesi Polri (KEPP) yang sangat dibutuhkan untuk terwujudnya pelaksanaan tugas yang dibebankan pada profesionalisme Kepolisian. Ketidak profesionalisme akan sangat berdampak dalam hal penegakan hukum atau pengungkapan kejahatan yang terjadi di masyarakat (Satjipto, 2002;2009).

Untuk menjalankan penegakan Kode Etik Profesi Polri maka diatur secara normatif dalam Undang-Undang No. 2 tahun 2002 tentang Kepolisian Republik Indonesia yang ditindaklanjuti dengan Peraturan Kapolri (Perkap) No. 14 Tahun 2011 tentang Kode Etik Profesi Polri. Sehingga Kode Etik Profesi Polri berlaku mengikat bagi setiap anggota Kepolisian Negara Republik Indonesia (Wawan, 2004;Wik Djatmika, 2007).

Upaya penegakan disiplin dan Kode Etik Profesi Polri (KEPP) sangat dibutuhkan guna terwujudnya pelaksanaan tugas yang dibebankan dan tercapainya profesionalisme Polri. Sangat tidak mungkin penegakan hukum dapat ber-jalan dengan baik, apabila penegak hukumnya sendiri (Polri) tidak disiplin dan tidak profesional. Ketidakdisiplinan dan ketidakprofesionalan Polri akan sangat berdampak dalam hal penegakan hukum atau pengungkapan kejahatan yang terjadi di masyarakat (Wiranata, 2005;Kansil, 2006).

Sesuai dengan masalah di atas, maka tujuan yang ingin dicapai dalam penelitian ini adalah untuk mengetahui bentuk pelanggaran dan penerapan sanksi yang diberikan kepada anggota Polri yang melanggar kode etik profesi kepolisian di wilayah hukum Kepolisian Daerah Sulawesi Selatan dan mengetahui akibat proses hukum yang timbul setelah penjatuhan putusan sidang Kode Etik Profesi Polri di Wilayah hukum Kepolisian Daerah Sulawesi Selatan (Sutanto, 2008; Van Apeldoorn, 2008).

\section{METODE PENELITIAN}

Berdasarkan perumusan masalah dan tujuan penelitian, maka metode yang digunakan pada penelitian ini adalah pendekatan normatif empiris. Maksudnya pendekatan yang dilakukan untuk menganalisa tentang sejauh manakah suatu peraturan atau perundang-undangan atau hukum yang sedang berlaku secara efektif mengenai pemecatan/pemberhentian anggota Polri melalui sidang kode etik profesi bagi anggota Polri yang melakukan pelanggaran

Sumber data adalah tempat dimana dapat ditemukannya data-data penelitian. Sumber-sumber tersebut dapat dibagi menjadi dua yaitu: Data Primer yaitu data yang diperoleh langsung dari hasil penelitian yang dilakukan oleh peneliti. Misalnya, dengan cara wawancara, observasi/pengamatan dan Data Sekunder yaitu data yang diperoleh dari pengkajian pustaka baik dari dari peraturan perundang-undangan ataupun sumber bacaan lain seperti buku, artikel, hasil penelitian ataupun dari media elektronik berupa media internet.

Untuk data primer, pengumpulan datanya dilakukan dengan cara mengadakan wawancara (Interview), yaitu dengan cara melakukan tanya jawab kepada pihak-pihak yang terkait ataupun yang menangani proses pelaksanaan pene- gakan sidang kode etik profesi anggota Polri yang melakukan pelanggaran.

Sedangkan untuk data sekunder, pengumpulan datanya dilakukan dengan cara menelaah dokumen-dokumen dan arsip-arsip yang ada kaitannya dengan objek penelitian yang diberikan oleh pihak yang terkait.

\section{HASIL DAN PEMBAHASAN}

3.1. Bentuk pelanggaran dan sanksi yang diberikan kepada Anggota Polri dalam Sidang Kode Etik Profesi Polri di wilayah hukum Kepolisian Daerah Sulawesi Selatan.

Dalam menegakkan disiplin dan kode etik profesi terhadap pelanggaran dan sanksi yang dijatuhkan kepada anggota Polri telah diatur di dalam Peraturan Pemerintah Nomor 2 Tahun 2003 tentang Peraturan Disiplin Anggota Polri dan Peraturan Kapolri Nomor 14 Tahun 2011 tentang Kode Etik Profesi Polri (Pudi, 2007;Muhammad, 2015).

Dalam menegakkan Kode Etik Profesi Polri (KEPP) bagi anggota Polri yang melanggar peraturan maka dibu-tuhkan wadah untuk melaksanakan proses penyelesaian pelanggaran yang sebagaimana telah diatur di dalam Pera-turan Kapolri Nomor 19 Tahun 2012 tentang Susunan Organisasi dan Tata Kerja Komisi Kode Etik Polri, yang dimana mengatur tentang pelaksanaan sidang bagi anggota Polri yang diduga melakukan pelanggaran KEPP (Warsito, 2005. Berikut Tabel pelanggaran anggota Polri berdasarkan golongan pangkat

Tabel 1

Pelanggaran Kode Etik Profesi Polri Berdasarkan Golongan Pangkat Tahun 2016-2019

\begin{tabular}{clc}
\hline No & Golongan Pangkat & Jumlah Pelanggaran \\
\hline 1 & Perwira Menengah & 5 \\
2 & Perwira Pertama & 13 \\
3 & Bintara & 56 \\
4 & Tamtama & 1 \\
\hline & Total & 75 \\
\hline
\end{tabular}

Sumber : Bidpropam Polda Sul-Sel 2019

Berdasarkan data Tabel 1, menujukkan bahwa pelanggaran terhadap Kode Etik Profesi Polri berdasarkan golongan pangkat dari tahun 2016 s/d tahun 2019, tercatat 5 (lima) pelanggaran dengan golongan pangkat Perwira Menengah, 13 pelanggaran dengan golongan pangkat Perwira Pertama dan 1 (satu) pelanggaran dengan golongan pangkat Tamtama sedangkan untuk pelanggaran yang paling banyak dengan 56 pelanggaran merupakan golongan pangkat Bintara.

Tabel 2

Bentuk Pelanggaran Kode Etik Profesi Polri Tahun 20162019

\begin{tabular}{clc}
\hline No & \multicolumn{1}{c}{ Bentuk Pelanggaran } & Jumlah \\
\hline 1 & Etika Kepribadian & 2 \\
2 & Etika Kenegaraan & - \\
3 & Etika Kelembagaan & 18 \\
4 & Etika Kemasyarakatan & - \\
5 & Pelanggaran Lain & 55 \\
\hline & Total & 75 \\
\hline
\end{tabular}

Sumber : Bidpropam Polda Sul-Sel 2019

Berdasarkan Tabel 2, menunjukkan bahwa bentuk pelanggaran Kode Etik Profesi Polri yang dilakukan ang-gota Polri dari tahun 2016-2019. pelanggaran terhadap Etika 
Kepribadian 2 kasus, Etika Kenegaraan 0 kasus, Etika Kelembagaan 18 kasus, Etika Kemasyarakatan 0 kasus dan Pelanggaran lain dengan 55 kasus. Mengenai pelanggaran lain merupakan pelanggaran yang paling sering dilakukan anggota Polri, adapun pelanggaran tersebut merupakan perbuatan pidana dan tindakan Desersi yang merupakan pengingkaran tugas atau jabatan tanpa permisi (pergi, bebas atau meninggalkan) dan dilakukan dengan tanpa tujuan kembali.

Adapun sanksi pelanggaran KEPP terhadap anggota Polri, pada wilayah hukum Polda Sul-sel sepanjang tahun 2016-2019, seperti pada Tabel 3 berikut :

Tabel 3

Sanksi Pelanggaran Kode Etik Profesi Polri Tahun 2016-2019

\begin{tabular}{clc}
\hline No & \multicolumn{1}{c}{ Sanksi Pelanggaran } & Jumlah \\
\hline 1 & Perbuatan Tercela & - \\
2 & Meminta Maaf & 11 \\
3 & Tidak Terbukti & - \\
4 & Pindah Tugas Jabatan & 5 \\
5 & Pindah Tugas Wilayah & 20 \\
6 & Pemberhentian Dengan Hormat & - \\
7 & Pemberhentian Tidak Dengan Hormat & 39 \\
& (PTDH) & 75 \\
\hline & Total
\end{tabular}

Sumber : Bidpropam Polda Sul-Sel 2019

Berdasarkan Tabel 3 di atas, sanksi pelanggaran terhadap Kode Etik Profesi Polri dari tahun 2016 s/d tahun 2019, sanksi pelanggaran dengan perbuatan tercela 0 anggota Polri, sanksi dengan meminta maaf 11 anggota Polri, sanksi dengan tidak terbukti 0 , sanksi dengan pindah tugas jabatan 5 anggota Polri, sanksi dengan pindah tugas wilayah 20 anggota Polri, sanksi dengan pemberhentian dengan hormat 0 anggota Polri dan sanksi dilakukan pemberhentian tidak dengan hormat (PTDH) 39 anggota Polri.

Berdasarkan penerapan sanksi pada tabel di atas, sanksi dengan pemberhentian tidak dengan hormat (PTDH) yang paling banyak dijatuhkan kepada anggota Polri yang melakukan pelanggaran KEPP, hal ini menunjukkan tingginya pelanggaran berat yang tidak dapat ditoleransi lagi atasan Ankum terhadap anggota Polri yang melanggar di wilayah hukum Polda Sul-Sel dan sikap tegas atasan Ankum dalam menjatuhkan sanksi terhadap anggota Polri yang melakukan pelanggaran KEPP.

Tabel 4

Pemberhentian Tidak dengan Hormat Polri Tahun 2016-2019

\begin{tabular}{cccc}
\hline No & & Tahun & Jumlah \\
\hline 1 & 2016 & 9 \\
2 & 2017 & 16 \\
3 & 2018 & 9 \\
4 & 2019 & 5 \\
\hline & Total & 39 \\
\hline
\end{tabular}

Sumber : Bidpropam Polda Sul-Sel 2019

Berdasarkan Tabel 4, menunjukkan bahwa pemberhentian Tidak Dengan Hormat (PTDH) anggota Polri yang melanggar Kode Etik Profesi Polri dari tahun 2016 s/d 2019, diketahui pada tahun 2016 ada 9 kasus PTDH, tahun 2017 ada 16 kasus PTDH, tahun 2018 ada 9 kasus PTDH dan 2019 ada 5 kasus PTDH. Sehingga berdasarkan data tersebut dapat disimpulkan sanksi PTDH bagi anggota
Polri pada tahun 2017 mengalami kenaikan 16 kasus dan tahun berikutnya mengalami penurunan, sehingga dapat dikata-kan sanksi PTDH mengalami penurunan dari tahun ke tahun

Sebelum dilakukannya PTDH bagi anggota Polri, harus dilandasi dengan beberapa hal atau alasan yang sangat tidak bisa ditoleransi lagi. Berikut ini hal-hal atau alasan, seorang anggota Polri dapat diberhentikan secara tidak terhormat yang dapat kita lihat pada Peraturan Kepala Kepolisian Negara Republik Indonesia Nomor 14 Tahun 2011 Tentang Kode Etik Profesi Kepolisian Republik Indonesia. Sanksi administratif berupa rekomendasi PTDH dikenakan kepada Pelanggar KEPP yang melakukan Pelanggaran meliputi:

a. Dipidana penjara berdasarkan putusan pengadilan yang telah mempunyai kekuatan hukum tetap dan menurut pertimbangan pejabat yang berwenang tidak dapat dipertahankan untuk tetap berada dalam dinas Polri

b. Diketahui kemudian memberikan keterangan palsu dan/ atau tidak benar pada saat mendaftarkan diri sebagai calon anggota Polri

c. Melakukan usaha atau perbuatan yang nyata-nyata bertujuan mengubah Pancasila, terlibat dalam gerakan, atau melakukan perbuatan yang menentang Negara dan/ atau Pemerintah Republik Indonesia

d. Melanggar sumpah/janji anggota Polri, sumpah/janji jabatan dan/atau KEPP

e. Meninggalkan tugasnya secara tidak sah dalam waktu lebih dari 30 (tiga puluh) hari kerja secara berturut-turut

f. Melakukan perbuatan dan berperilaku yang dapat merugikan dinas kepolisian

g. Melakukan bunuh diri dengan maksud menghindari penyidikan dan/atau tuntutan hukum atau meninggal dunia sebagai akibat tindak pidana yang dilakukannya

h. Menjadi anggota dan/atau pengurus partai politik yang diketahui kemudian telah menduduki jabatan atau menjadi anggota partai politik dan setelah diperingatkan/ ditegur masih tetap mempertahankan statusnya itu

i. Dijatuhi hukuman disiplin lebih dari 3 (tiga) kali dan dianggap tidak patut lagi dipertahankan statusnya sebagai anggota Polri.

3.2. Implikasi Proses Hukum yang Timbul Setelah Penjatuhan Putusan Sidang Komisi Kode Etik Profesi Polri di Wilayah Hukum Kepolisian Daerah Sulawesi Selatan

Terjadinya pelanggaran Kode Etik Profesi Polri yang dilakukan anggota Polri maka penanganannya melalui sidang Komisi Kode Etik Polri (KKEP), bilamana terjadi pelanggaran KEPP yang dilandasi dengan beberapa hal atau alasan yang sangat tidak bisa ditoleransi lagi, maka dalam sidang KKEP tersebut anggota Polri tersebut dapat diberi sanksi berat dengan dilakukan Pemberhentian Tidak dengan Hormat (PTDH).

Dengan adanya proses dan putusan sidang KKEP bagi anggota Polri yang melakukan pelanggaran KEPP, tentunya akan berdampak bagi anggota Polri, diantaranya

a) Terhadap anggota Polri yang melanggar tidak dapat berkarir atau memiliki jabatan selama 6 bulan.

b) Adanya pengawasan dan penilaian terhadap anggota Polri yang dilaksanakan oleh pengemban fungsi Propam Polri bidang rehabilitasi personel, yang teknis pengawasannya dilaksanakan dan menjadi tanggung jawab Kepala Kesatuan Pelanggar. 
c) Akan memberikan efek jera bagi anggota Polri yang melakukan pelanggaran, dan bagi anggota Polri yang lain akan menjadi bahan pembelajaran untuk tidak melakukan pelanggaran.

d) Jumlah pelanggaran anggota Polri dari tahun ketahun mengalami penurunan

e) Adanya perubahan sikap dan perilaku anggota Polri yang lebih bertanggungjawab dalam melaksanakan tugas dan kewajibannya setelah adanya putusan sidang KKEP, dengan pengawasan pelaksanaan Putusan Sidang KEPP, yang dilaksanakan oleh pengemban fungsi Propam Polri bidang rehabilitasi personel.

Pelanggaran yang dilakukan oleh anggota Polri tidak serta merta selesai melalui Sidang Disiplin dan Sidang Komisi Kode Etik Polri, sehingga hasilnya sering tidak sesuai ketentuan hukum atau aturan yang diberlakukan. Sebagai suatu ilustrasi dalam hasil sidang Komisi Kode Etik Polri (KKEP) memberikan sanksi rekomendasi Pemberhentian Tidak Dengan Hormat (PTDH) bahwa anggota Polri tersebut telah melanggar Disiplin Polri dan Kode Etik Profesi Polri (KEPP) sehingga sudah tidak layak menjadi anggota Polri karena kesalahannya, namun demikian rekomendasi tersebut tidak dipenuhi oleh Atasan Yang Berhak Menghukum (Ankum) karena adanya berbagai pertimbangan misalnya faktor kedekatan (personal interested) antara Ankum dengan Pelanggar atau adanya kebijakan lain sehingga masih dipertahankan.

Berdasarkan hasil penelitian penulis, didapatkan beberapa data penyimpangan putusan sidang KKEP, yang seharusnya diberikan sanksi berupa rekomendasi PTDH namun tetap dipertahankan dan hanya diberikan sanksi yang lain. Yang dapat diuraikan pada Tabel 5 di bawah ini:

Tabel 5

Penyimpangan Putusan Sanksi PTDH Dalam Proses Hukum KKEP

\begin{tabular}{|c|c|c|}
\hline No & Tahun & Kasus Pelanggaran \\
\hline 1 & 2016 & $\begin{array}{l}\text { Tindak pidana narkotika } 4 \text { kasus, dengan } \\
\text { sanksi pindah tugas wilayah }\end{array}$ \\
\hline 2 & 2017 & $\begin{array}{l}\text { Tindak pidana narkotika } 2 \text { kasus, disersi } 1 \\
\text { kasus, mendapatkan SKHD tiga kali } 1 \\
\text { kasus, dengan sanksi perbuatan tercela, } \\
\text { permintaan maaf dan pindah tugas }\end{array}$ \\
\hline 3 & 2018 & $\begin{array}{l}\text { wilayah Tindak pidana narkotika } 6 \text { kasus, } \\
\text { tindak pidana penggelapan } 1 \text { kasus dan } \\
\text { disersi } 1 \text { kasus, dengan sanksi perbuatan } \\
\text { tercela, permintaan maaf dan pindah } \\
\text { tugas wilayah dan jabatan }\end{array}$ \\
\hline
\end{tabular}

Total 17 Kaus

Sumber : Bidpropam Polda Sul-Sel 2019

Berdasarkan Tabel 5 menunjukkan bahwa jenis pelanggaran yang dilakukan anggota Polri yaitu penyalahgunaan narkotika, Disersi, Pidana penggelapan dan 3 (tiga) kali mendapatkan Surat Keputusan Hukuman Disiplin (SKHD) yang merupakan jenis pelanggaran berat yang sudah tidak layak menjadi anggota Polri karena kesalahannya yang dimungkinkan untuk pemberian sanksi PTDH, namun dalam putusan sidang Komisi Kode Etik Polri, Pelanggar hanya diberikan sanksi yang lain seperti meminta maaf, pindah wilayah atau pindah fungsi jabatan.

\section{KESIMPULAN}

Berdasarkan hasil penelitian, dapat disimpulkan bahwa, bentuk pelanggaran dan penerapan sanksi yang dibe-rikan kepada anggota Polri yang melanggar Kode Etik Profesi Polri (KEPP) di wilayah hukum Kepolisian Dae-rah Sulawesi Selatan yang dilaksanakan dalam sidang Komisi Kode Etik Polri (KKEP) mencakup pelanggaran terhadap Etika kepribadian, Etika kenegaraan, Etika kelembagaan, Etika dalam hubungan dengan masyarakat dan Pelanggaran lainnya sedangkan sanksi pelanggaran yang dijatuhkan yaitu Perbuatan Tercela, Meminta Maaf, Pindah Tugas Jabatan, Pindah Tugas Wilayah, Pemberhentian Dengan Hormat (PDH) dan Pemberhentian Tidak dengan Hormat (PTDH); dan Impli-kasi proses hukum yang timbul setelah penjatuhan putusan sidang Kode Etik Profesi Polri (KEPP) dalam sidang Komisi Kode Etik Polri (KKEP) di Wilayah hukum Kepolisian Daerah Sulawesi Selatan. Bagi anggota yang melakukan pelanggaran berat pidana dan disersi serta terbukti dalam proses sidang KKEP maka akan dikeluarkannya rekomendasi Pemberhentian Tidak dengan Hormat (PTDH)

\section{DAFTAR PUSTAKA}

Abintro Prakoso. (2015). Etika Profesi Hukum. Laksbang Justitia. Surabaya

Ali Subur. (2007). Pergulatan Profesionalisme dan Watak Pretorian (Catatan Kontras Terhadap Kepolisian ). Kontras. Jakarta

Kansil, C.S.T (2006). Pokok-pokok Etika Profesi Hukum. Pradnya Paramita. Jakarta

I Gede A.B. Wiranata. 2005. Dasar-dasar Etika dan Moralitas. Citra Aditya Bakti. Bandung.

Mansyur, A. (2019). Tinjauan Yuridis Terhadap Pemberhentian Tidak Dengan Hormat Dari Dinas Anggota Kepolisian Negara Republik Indonesia Di Kabupaten Bone.

Muhamad Erwin. (2015). Filsafat Hukum, Refleksi Kritis Terhadap Hukum dan Hukum Indonesia (dalam Dimensi Ide dan Aplikasi). RajaGrafindo Persada. Jakarta

Pudi Rahardi. (2007). Hukum Kepolisian, Profesionalisme, dan Reformasi Polri. Laksbang Mediatania. Surabaya

Sadjijono. (2010). Memahami Hukum Kepolisian, Cet I. Laksbang Presindo. Yogyakarta

Satjipto Rahardjo. (2003). Mengkaji Kembali Peran dan Fungsi Polri dalam Era Reformasi. Makalah Seminar Nasional. Jakarta

(2009). Penegakan Hukum Suatu Tinjauan Sosiologis. Genta Publishing. Yogyakarta

Sutanto. (2008). Polmas Filsafat Baru Pemolisian. Pensil324. Jakarta

Van Apeldoorn. (2008). Pengantar Ilmu Hukum. Pradnya Paramitha. Jakarta

Warsito Hadi Utomo. (2005). Hukum Kepolisian di Indonesia. Prestasi Pustaka. Jakarta

Wawan Tunggul Alam. (2004). Memahami Profesi Hukum Hakim, Jaksa, Polisi, Notaris, Advokat dan Konsultan Hukum Pasar Modal. Milenial Populer. Jakarta

Wik Djatmika. (2007). Etika Kepolisian (dalam Komunitas Spesifik Polri), Jurnal Kepolisian. STIK-PTIK.Edisi 75. 